\title{
カテゴリカルデータの散布度について
}

統計数理研究所 鈴 木 義一郎

\section{Some Concept of Dispersion Measure for Categorical Data}

Giitiro SuzukI

要 旨 順序尺度のあるカテゴリカルデータに対して, 隣あったカテゴリー間には 1,2 つ離れていれば 2 というように数値を与えてやれば，「平均差」に対応するもの で散布度の尺度を与えることができる。また名目尺度のデータに対しては，異なる カテゴリー間全てに 1 の距離があるものと解釈すれば, 同様の散布度の尺度が定義 できる。

「日本人の国民性調査』のデータを例に，これらの尺度が質問に対する回答パター ンの相違を端的にはじきだすのに有用であることを示す.なお順序尺度の場合には， 標準偏差とほほ同じような值をとるが, 平方值をとらないので, 標準偏差よりも散 布パターンを的確に与える尺度であることも示される。

さらに，大相撲のデータなどの分析に対しても，これらの尺度が有用であること を示す．また，大相撲の各力士の勝相撲での決り手のパターンなどのように，カテ ゴリーの数が多いデータの散布度を捉えるときなどには, 名目尺度のデータに対す る散布度を多少修正して用いるほうがよいという事例も紹介する。

\section{1. 順序尺度データの散布度}

$n$ 個のデータ $\left\{x_{1}, x_{2}, \ldots, x_{n}\right\}$ に対して

$$
d=\frac{1}{n(n-1)} \sum_{i=1}^{n} \sum_{j=1}^{n}\left|x_{i}-x_{j}\right|
$$

によって定義されるものが, Gini (1913) によって導入された「平均差」である. 標準偏差が平均 からのずれの平均であるのに対して，この平均差のほうは各データ間のずれの平均である.

順序尺度のカテゴリカルデータが与えられている場合に， $i$ 番目のカテゴリ一の観測度数を $f_{i}$ とする $(i=0,1, \ldots, m)$. 隣あったカテゴリー間の距離を 1 と考えると

$$
\sum_{i=1}^{n} \sum_{j=1}^{n}\left|x_{i}-x_{j}\right| \Leftrightarrow \sum_{i \neq j}^{m}|i-j| f_{i} f_{j}
$$

といった対応になる.

そこで, 次のような第 1 , 第 2 累積度数を定義する.

Key words: mean difference, dispersion measure, ordinal or nominal-scale data, Japanese Nationality, OUZUMOU data (Professional Japanese Wrestling). 


$$
\begin{aligned}
& g_{j}=\sum_{i=j}^{m} f_{i} \quad(j=1,2, \ldots, m) \\
& h_{k}=\sum_{j=k}^{m} g_{j}=\sum_{j=k}^{m} \sum_{i=j}^{m} f_{i}=\sum_{i=k}^{m} \sum_{j=k}^{i} f_{j}=\sum_{i=k}^{m}(i-k+1) f_{i} \quad(k=1,2, \ldots, m) .
\end{aligned}
$$

すると

$$
\begin{aligned}
u & =\sum_{j=0}^{m-1} \sum_{j+1}^{m}(i-j) f_{i} f_{j}=\sum_{j=0}^{m-1} f_{j} \sum_{j+1}^{m}(i-j) f_{i} \\
& =\sum_{k=1}^{m} f_{k-1} \sum_{i=k}^{m}(i-k+1) f_{i}=\sum_{k=1}^{m} f_{k-1} h_{k}
\end{aligned}
$$

であるから

$$
v=\frac{2}{n(n-1)} u, n=\sum_{j=0}^{m} f_{i}
$$

で与えられるものが, 順序尺度デー夕の散布度を表わすことになる.

さらに，絶対差の代わりに差の平方を考えてみると

\begin{tabular}{|c|c|c|c|c|c|c|c|}
\hline & (1) & (2) & (3) & (4) & $v$ & $s$ & \\
\hline 男 & 194 & 516 & 73 & 41 & 0.694 & 0.722 & \\
\hline 女 & 248 & 606 & 81 & 39 & 0.673 & 0.700 & \\
\hline 計 & 442 & 1,122 & 154 & 80 & 0.683 & 0.710 & \\
\hline $20 \sim 24$ & 20 & 104 & 13 & 7 & 0.575 & 0.649 & \\
\hline $25 \sim 29$ & 33 & 82 & 16 & 9 & 0.780 & 0.779 & (1) 必ず過ごしたいと思う \\
\hline $30 \sim 34$ & 21 & 97 & 19 & 6 & 0.624 & 0.665 & (2) できれば過ごしたいと思う \\
\hline $35 \sim 39$ & 34 & 106 & 11 & 4 & 0.571 & 0.620 & (3) あまり過ごしたいとは思わない \\
\hline $40 \sim 44$ & 49 & 163 & 17 & 12 & 0.633 & 0.687 & (4) 過ごしたいとは思わない \\
\hline $45 \sim 49$ & 57 & 121 & 19 & 8 & 0.709 & 0.718 & \\
\hline $50 \sim 54$ & 42 & 106 & 20 & 6 & 0.691 & 0.701 & \\
\hline $55 \sim 59$ & 43 & 111 & 10 & 7 & 0.638 & 0.679 & \\
\hline $60 \sim 64$ & 59 & 107 & 10 & 9 & 0.715 & 0.734 & \\
\hline $65 \sim 69$ & 42 & 54 & 11 & 6 & 0.831 & 0.808 & \\
\hline $70 \sim$ & 42 & 71 & 8 & 6 & 0.735 & 0.743 & \\
\hline
\end{tabular}

$$
\begin{aligned}
\sum_{i \neq j}^{m}(i-j)^{2} f_{i} f_{j} & =\sum_{i=1}^{m} \sum_{j=1}^{m}(i-j)^{2} f_{i} f_{j} \\
& =\sum_{i=1}^{m} \sum_{j=1}^{m}\left(i^{2}-2 i j+j^{2}\right) f_{i} f_{j} \\
& =\sum_{i}^{m} i^{2} f_{i} \sum_{j}^{m} f_{j}-2 \sum_{i}^{m} i f_{i} \sum_{j}^{m} j f_{j}+\sum_{j}^{m} j^{2} f_{j} \sum_{i}^{m} f_{i} \\
& =2 n \sum_{i=1}^{m} i^{2} f_{i}-2\left(\sum_{i=1}^{m} i f_{i}\right)^{2}=2 n^{2} s^{2}
\end{aligned}
$$

ここで

$$
s^{2}=\frac{1}{n} \sum_{i=0}^{m} i^{2} f_{i}-\left[\frac{1}{n} \sum_{i=0}^{m} i f_{i}\right]^{2}
$$

表 1. 親族と過ごす（国民性調查 平成 5 年） 
は，カテゴリーが順次 $0,1, \cdots, m$ という数值をとるものとしたときの通常の標本分散に他ならな い. したがって，この平方根（つまり標準偏差）が順序尺度データの散布度を表わすとみなす ともできる。

表 1 は，『日本人の国民性調査』で，「扮盆の頃，いつもは別々に住んでいる親族と一緒に時を 過ごしたいと思いますか」という質問に対する回答パターンを性別と年齢別に集計した結果であ る（統計数理研究所国民性調查委員会 (1994)). 右端の 2 列に $v$ と $s$ 值を示してみたが, 両者 はほぼ似たようなパターンで変動していることが分かる.ただ, $v$ の值では, 40〜 44 歳より 55〜 59 歳のグループの方が高い. 一方 $s$ の值では大小関係が逆転している，これは, 最も離れたカテゴ リーである (1) と (4)での度数の積が 40〜44 歳で 588, 55〜59 歳で 301 のように差が大きい. この

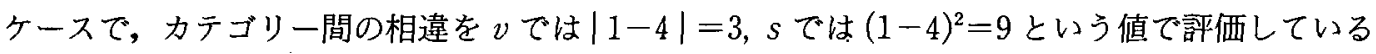
ために生じた “逆転劇”である.カテゴリーの数がさらに大きくなると, 平方差による評価が離れ たカテゴリーを不当に離れさせてしまう傾向が顕著になる。

そこで図 1 に，両グループのパターンの違いをパーセント表示してみた．感覚的にみると，40 〜4 歳グループのほうがやや集中していると思われるので, $s$ より $v$ というスコアのほうが数 值も小さく適当なように思われる.

男女別では，回答の散布度はほとんど違わない(図 2 参照). 年歯別では，35〜39 歳階級の $v$ の 值が最小で, (2)のカテゴリーに 3 分の 2 の回答が集中しているためである.反対に $v$ の值が大き 认のは 65〜69 歳階級で, 両グループでの回答の散布パターンの相違を示してみたのが図 3 であ

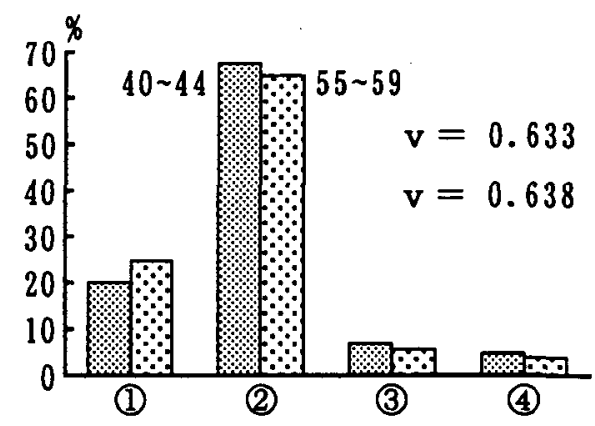

図 1. $40 \sim 44$ 歳と 55〜59 歳の相違

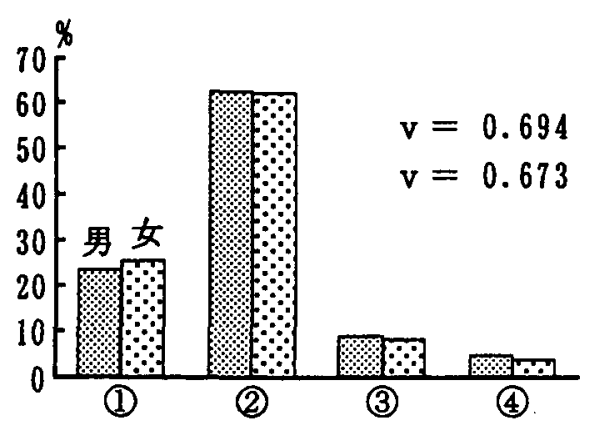

図 2. 男と女の解答パターン

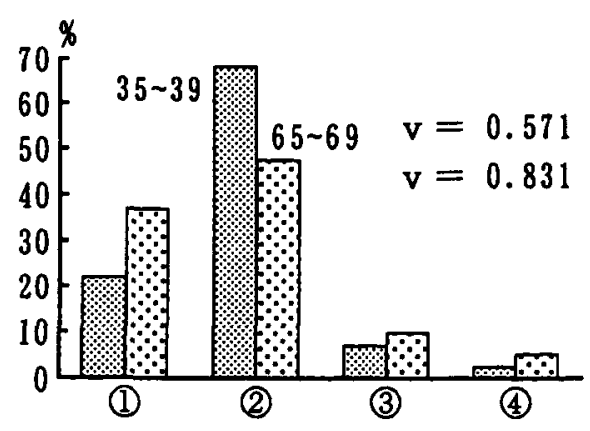

図 3. $35 \sim 39$ 歳と 65〜 69 歳の相違 
る. 65〜69 歳階級は親戚と過ごしたいという思いが強くなる年代で,カテゴリー (1)への比率が高 くなる. また一方では, (3), (4)への回答も 40〜44 歳グループより高く, 意識が多様化している傾

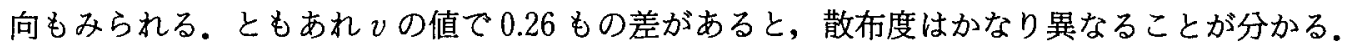

\section{2. 名目尺度のカテゴリカルデータの場合}

次に, 名目尺度のカテゴリカルデータが与えられている場合を考える。順番はないが, 便宜上 カテゴリーに番号を付して， $i$ カテゴリーの観測度数を $f_{i}$ とする $(i=1,2, \ldots, m)$. カテゴリー間 には距離のようなものがないから

$$
\sum_{i=1}^{n} \sum_{j=1}^{n}\left|x_{i}-x_{j}\right| \Leftrightarrow \sum_{i \neq j}^{m} f_{i} f_{j}=n^{2}-\sum_{i=1}^{m} f_{i}^{2} \quad\left(n=\sum_{i=1}^{m} f_{i}\right)
$$

のように考えると

$$
D=1-\left(\sum_{i=1}^{m} f_{i}^{2}\right) / n^{2}
$$

といったものが平均差に対応する散布度と解釈できる。

カテゴリーの数が $m$ 個あり, それらのカテゴリーに属する確率が $p_{1}, p_{2}, \ldots, p_{m}$ のように与えら れているとする．観測個数が $n$ の場合に, $f=\left(f_{1}, f_{2}, \cdots, f_{m}\right)$ という観測度数ベクトルは

$$
\begin{aligned}
p_{n, m}(f) & =p_{n, m}\left(f_{1}, f_{2}, \ldots, f_{m}\right) \\
& =\frac{n !}{f_{1} ! f_{2} ! \cdots \cdots f_{m} !} p_{1}{ }^{f_{1}}{p_{2}}^{f_{2}} \cdots p_{m}{ }^{f_{m}} \\
& =\left\{n p_{i} / f_{i}\right\} p_{n-1, m}\left(f_{1}, f_{2}, \cdots, f_{i}-1, \cdots, f_{m}\right) \\
& =\left\{n(n-1) / f_{i}\left(f_{i}-1\right)\right\}_{p_{i}}{ }^{2} p_{n-2, m}\left(f_{1}, f_{2}, \cdots, f_{i}-2, \cdots, f_{m}\right)
\end{aligned}
$$

という多項分布に従う。

$$
\text { そこで }
$$

$$
1 \leqq f_{i} \leqq n, 1 \leqq f_{j} \leqq n \quad(j \neq i), \quad f_{1}+f_{2}+\cdots+f_{m}=n
$$

を満足する全ての整数値の組合せについての和を $\Sigma_{1}$ とすると

$$
\begin{aligned}
E\left\{f_{i}\right\} & =\sum f_{i} \cdot p_{n, m}\left(f_{1}, f_{2}, \ldots, f_{m}\right) \\
& =n p_{i} \Sigma_{1} p_{n-1, m}\left(f_{1}, f_{2}, \ldots, f_{i}-1, \ldots, f_{m}\right)=n p_{i}
\end{aligned}
$$

同様に

$$
2 \leqq f_{i} \leqq n, 2 \leqq f_{j} \leqq n \quad(j \neq i), \quad f_{1}+f_{2}+\cdots+f_{m}=n
$$

を満足する組合せの和を $\Sigma_{2}$ とすると

$$
\begin{aligned}
E\left\{f_{i}\left(f_{i}-1\right)\right\} & =\Sigma f_{i}\left(f_{i}-1\right) \cdot p_{n-2, m}\left(f_{1}, f_{2}, \cdots, f_{m}\right) \\
& =n(n-1) p_{i}{ }^{2} \sum_{2} p_{n-2, m}\left(f_{1}, f_{2}, \cdots, f_{i}-2, \cdots, f_{m}\right) \\
& =n(n-1) p_{i}{ }^{2}
\end{aligned}
$$

であるから

$$
E\left\{f_{i}^{2}\right\}=E\left\{f_{i}\right\}+E\left\{f_{i}\left(f_{i}-1\right)\right\}=n^{2} p_{i}^{2}+n p_{i}\left(1-p_{i}\right)
$$


表 2.人のくらし方（日本人の国民性調查 平成 5 年）

\begin{tabular}{|c|c|c|c|c|c|c|c|c|c|c|c|}
\hline & (1) & (2) & (3) & (4) & (5) & (6) & (7) & (8) & $d$ & & \\
\hline 男 & 323 & 55 & 695 & 363 & 126 & 90 & 28 & 44 & 0.748 & & \\
\hline 女 & 307 & 44 & 794 & 593 & 99 & 66 & 35 & 76 & 0.729 & & \\
\hline 計 & 680 & 99 & 1,489 & 956 & 225 & 156 & 63 & 120 & 0.740 & & \\
\hline $20 \sim 24$ & 47 & 10 & 162 & 58 & 12 & 3 & 4 & 7 & 0.661 & & 一生懸命働き金持ちになる \\
\hline $25 \sim 29$ & 55 & 11 & 131 & 58 & 12 & 7 & 1 & 5 & 0.710 & (2) & まじめに勉強し名をあげる \\
\hline $30 \sim 34$ & 54 & 8 & 154 & 61 & 7 & 10 & 3 & 13 & 0.688 & (3) & 自分の趣味にあった暮らし \\
\hline $35 \sim 39$ & 52 & 10 & 133 & 89 & 16 & 11 & 7 & 11 & 0.759 & (4) & クヨクヨせずのんきに暮らす \\
\hline $40 \sim 44$ & 96 & 10 & 205 & 97 & 21 & 19 & 10 & 21 & 0.737 & (5) & 清く正しく暮らす \\
\hline $45 \sim 49$ & 74 & 10 & 178 & 95 & 23 & 18 & 9 & 15 & 0.724 & (6) & 社会のために全てささげる \\
\hline $50 \sim 54$ & 62 & 8 & 149 & 79 & 30 & 14 & 11 & 13 & 0.779 & (7) & その他（記入） \\
\hline $55 \sim 59$ & 65 & 11 & 128 & 86 & 29 & 25 & 7 & 13 & 0.785 & (8) & D.K. \\
\hline $60 \sim 64$ & 51 & 8 & 123 & 132 & 29 & 16 & 5 & 9 & 0.767 & & \\
\hline $65 \sim 69$ & 37 & 5 & 65 & 89 & 28 & 15 & 3 & 5 & 0.772 & & \\
\hline $70 \sim$ & 36 & 9 & 61 & 112 & 18 & 18 & 3 & 8 & 0.727 & & \\
\hline
\end{tabular}

$$
E\left\{\Sigma f_{i}^{2}\right\}=\Sigma E\left\{f_{i}^{2}\right\}=n^{2} \sum p_{i}^{2}+n\left(1-\sum p_{i}^{2}\right)
$$

これより, 統計量 $D$ の期待值は

$$
E\{D\}=1-\frac{1}{n^{2}} E\left\{\Sigma f_{i}^{2}\right\}=\frac{n-1}{n}\left\{1-\Sigma p_{i}{ }^{2}\right\}
$$

この值は $n \rightarrow \infty$ とすると

$$
\delta=\left\{1-\Sigma p_{i}{ }^{2}\right\}
$$

に近づくから，これが母集団の散布度を表わすパラメータであると解釈できる，従って，

$$
d=\frac{n}{n-1} D=\left\{n-\left(\sum f_{i}^{2}\right) / n\right\} /(n-1)
$$

が $\sigma$ に対する不偏推定量となる.

表 2 も日本人の国民性調査で，人のくらし方に関する質問の回答パターンを性別と年齢別に集 計した結果である. 最終列に $d$ の値を示してみた. 男女別では，回答の散布度はそれほど違わな

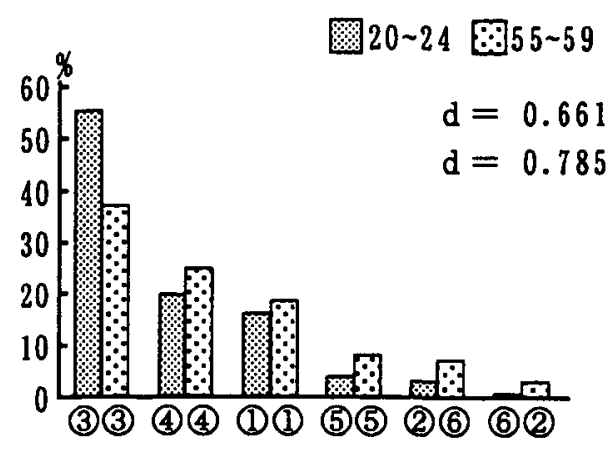

図 4. $20 \sim 24$ 歳と $55 \sim 59$ 歳の相違

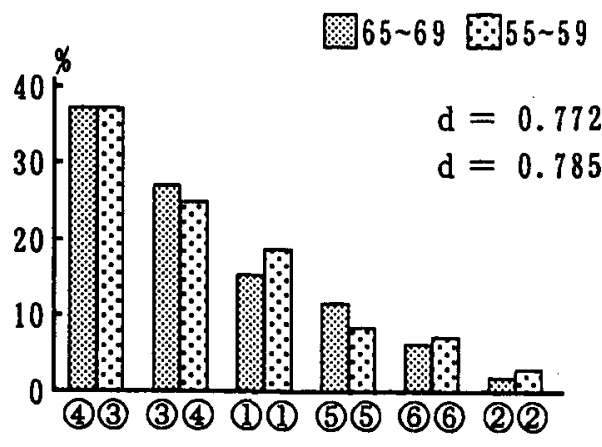

图 5. 65 69 歳と 55〜59 歳の相違 
い.ただし内容の違いには言及していない. 年齢別では, 20〜24 歳階級で $d$ の值が最小で, (3)の 趣味にあった暮らしを志向するタイプが半分以上いるためである.反対に $d$ の値が大きいのは 55 〜 59 歳階級で, 暮らし方が多様化する年代である.

20〜24 歳と 55〜59 歳のグループでの回答の散布パターンの相違を示してみたのが図 4 であ る. $d$ の值で 0.124 もの差があると, 散布度はかなり異なることが分かる.さらに図 5 には, 55〜 59 歳階級と 65〜69 歳階級での相違を示してみた. $d$ の值では 0.013 しか違いがないので, この程度 の差では散布パターンの違いは識別できない.ただ前者での最大の回答は (3)の「趣味にあった暮 らし」であるのに対して, 後者では (4)のカテゴリーの「のんきに暮らす」が 1 位を占めているの で, 回答の内容まで含めてパターンの違いを示してはいないことに注意する必要がある.

\section{3. 大相撲のデータへの適用例}

表 3 に示したのは, 横綱貴乃花が大関になる前 10 場所についての勝敗の系列（1 が勝ち，0が 負け）である（読売新聞社（1990-92）の複数年より集積したデータ).このデータから, 表 4 の ような連敗のパターンを作成する.つまり, 最初が 0 敗 (つまり勝数), 次が単敗, 2 連敗, ….... といった回数を示している. 例えば 8 場所前の系列を眺めると, 勝ちが 7 , 単敗が 1 度, 2 連敗が

表 3. 貴花田の大関前 10 場所の勝敗系列

\begin{tabular}{c|ccccccccccccccc}
\hline 場所数 & 1 & 2 & 3 & 4 & 5 & 6 & 7 & 8 & 9 & 10 & 11 & 12 & 13 & 14 & 15 \\
\hline 10 & 1 & 0 & 0 & 1 & 0 & 1 & 1 & 1 & 1 & 1 & 0 & 1 & 1 & 1 & 1 \\
9 & 1 & 1 & 1 & 0 & 0 & 0 & 0 & 0 & 1 & 1 & 1 & 0 & 0 & 0 & 1 \\
8 & 0 & 1 & 1 & 1 & 0 & 0 & 0 & 1 & 1 & 0 & 0 & 1 & 0 & 0 & 1 \\
7 & 1 & 1 & 0 & 1 & 1 & 1 & 1 & 1 & 1 & 1 & 1 & 1 & 1 & 1 & 1 \\
6 & 0 & 0 & 0 & 1 & 1 & 1 & 0 & 0 & 1 & 1 & 0 & 0 & 0 & 0 & 0 \\
5 & 0 & 1 & 0 & 1 & 0 & 1 & 1 & 1 & 1 & 1 & 0 & 1 & 0 & 0 & 1 \\
4 & 1 & 0 & 0 & 0 & 1 & 0 & 0 & 1 & 1 & 0 & 1 & 1 & 0 & 1 & 1 \\
3 & 1 & 1 & 1 & 0 & 1 & 1 & 1 & 1 & 1 & 1 & 1 & 1 & 1 & 1 & 1 \\
2 & 0 & 0 & 0 & 0 & 1 & 1 & 1 & 1 & 1 & 1 & 1 & 1 & 1 & 0 & 1 \\
1 & 1 & 1 & 1 & 1 & 1 & 1 & 1 & 0 & 1 & 0 & 0 & 1 & 1 & 1 & 0 \\
\hline
\end{tabular}

表 4. 貴花田の連敗度のパターン

\begin{tabular}{c|rrrrrr|c|c}
\hline 場所数 & 0 & 1 & 2 & 3 & 4 & 5 & $v$ & $s$ \\
\hline 10 & 11 & 2 & 1 & & & & 0.505 & 0.589 \\
9 & 7 & 0 & 0 & 1 & 0 & 1 & 1.611 & 1.728 \\
8 & 7 & 1 & 2 & 1 & & & 1.127 & 1.052 \\
7 & 14 & 1 & & & & & 0.133 & 0.249 \\
6 & 5 & 0 & 1 & 1 & 0 & 1 & 2.000 & 1.785 \\
5 & 9 & 4 & 1 & & & & 0.637 & 0.623 \\
4 & 8 & 2 & 1 & 1 & & & 0.955 & 0.954 \\
3 & 14 & 1 & & & & & 0.133 & 0.249 \\
2 & 10 & 1 & 0 & 0 & 1 & & 0.803 & 1.115 \\
1 & 11 & 2 & 1 & & & & 0.505 & 0.573 \\
\hline
\end{tabular}


表 5. 3 場所の連敗と連敗度のパターン

\begin{tabular}{c|cccccc|c|c}
\hline 場所数 & 0 & 1 & 2 & 3 & 4 & 5 & $v$ & $s$ \\
\hline 8 & 25 & 3 & 3 & 2 & 0 & 1 & 0.934 & 1.166 \\
7 & 28 & 2 & 2 & 2 & 0 & 1 & 0.857 & 1.131 \\
6 & 26 & 2 & 3 & 2 & 0 & 1 & 0.954 & 1.168 \\
5 & 28 & 2 & 2 & 1 & 0 & 1 & 0.790 & 1.029 \\
4 & 22 & 6 & 3 & 2 & 0 & 1 & 1.053 & 1.156 \\
3 & 31 & 7 & 2 & 1 & & & 0.556 & 0.685 \\
2 & 32 & 4 & 1 & 1 & 1 & & 0.599 & 0.857 \\
1 & 35 & 4 & 1 & 0 & 1 & & 0.449 & 0.725 \\
\hline
\end{tabular}

2 度, 3 連敗が 1 度ある.この表で $v$ の值が 2 と最大になるときは， 2 連敗， 3 連敗， 5 連敗を 1 回 ずつしている，反対に， 7 場所前と 3 場所前のように，単敗が 1 度しかない場合には，vの值は 0 . 133 のように，小さな値になる（全勝なら $v$ は 0 になる）.

また表 5 には, 連続した 3 場所の成績をまとめたときの連敗と連敗度のパターンを示してみた. 大関になる直前の 5 場所目以降から，3 場所まとめた成績のパターンでの $v$ の值が 0.6 以下と なっていて，安定した力のついてきたことなどが読みとれる.ただ $s$ の值のほうで眺めてみると， 5 場所前から 3 場所前までのデー夕に対して小さな值になっている。これは, $s^{2}$ の值の計算で差の 平方值を用いているために, 4 連敗が 1 度あるということがより大きな值を与える結果になる.そ の点, 絶対差で評価するvのほうが離れたカテゴリーに余り影響されないので, 特にカテゴリー 数が多いようなデータに対しては，vを用いたほうが安全であることが分かる.

次に名目尺度のデータに対する $D$ という尺度も, データ数があまり大きくない場合には少し難 点がある. 図 6〜図 11 は，いろんな力士が勝ったときの決り手の分布パターンである。これらの データに対して $D$ の值を示してみたが，たとえば貴乃花の図 6 と図 7 に対する $D$ の値はほ注同 じである.しかし 14 勝のうち 5 種類の手を用いるよりも，80勝を 17 種類で済ましているほうが むしろ安定しているとも考えられる。また図 9 (双葉山) と図 10 (大鵬) のDの値も活注同じだ が，大鵬の散布度のほうが大きい感じがする。つまり $D$ という尺度は，少ないデータのときには 小さめの值を与える傾向のあることが分かる。

表 6. カテゴリー数とウェイト (10,000 回のシミュレーション)

\begin{tabular}{r|rccccccc}
\hline \multicolumn{1}{r}{$n$} & NEC & $k$ & $D$ & $\alpha=1 / 10$ & $\alpha=1 / 8$ & $\alpha=1 / 6$ & $\alpha=1 / 4$ & $\alpha=1 / 2$ \\
\hline 5 & 3.40 & 3.297 & 0.618 & 0.596 & 0.591 & 0.583 & 0.566 & 0.521 \\
10 & 5.21 & 5.230 & 0.697 & 0.654 & 0.643 & 0.627 & 0.594 & 0.509 \\
15 & 6.59 & 6.580 & 0.722 & 0.665 & 0.651 & 0.629 & 0.588 & 0.480 \\
20 & 7.75 & 7.735 & 0.735 & 0.668 & 0.653 & 0.627 & 0.580 & 0.458 \\
25 & 8.77 & 8.769 & 0.743 & 0.669 & 0.651 & 0.623 & 0.571 & 0.441 \\
30 & 9.69 & 9.681 & 0.747 & 0.667 & 0.648 & 0.619 & 0.563 & 0.425 \\
40 & 11.32 & 11.329 & 0.754 & 0.664 & 0.644 & 0.611 & 0.550 & 0.401 \\
50 & 12.76 & 12.782 & 0.759 & 0.661 & 0.639 & 0.603 & 0.539 & 0.383 \\
60 & 14.06 & 14.072 & 0.761 & 0.659 & 0.634 & 0.597 & 0.530 & 0.368 \\
80 & 16.36 & 16.382 & 0.764 & 0.652 & 0.626 & 0.586 & 0.513 & 0.345 \\
100 & 18.39 & 18.389 & 0.766 & 0.646 & 0.619 & 0.576 & 0.501 & 0.328 \\
\hline
\end{tabular}




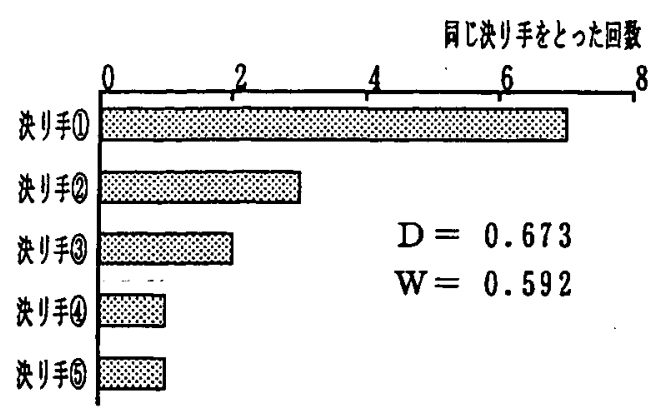

図 6. 責乃花の決り手 (平成 8 年初場所)

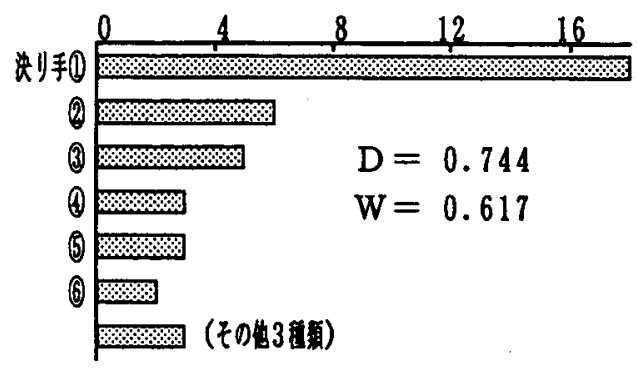

図 8. 曙三連覇 (40 勝) の決り手

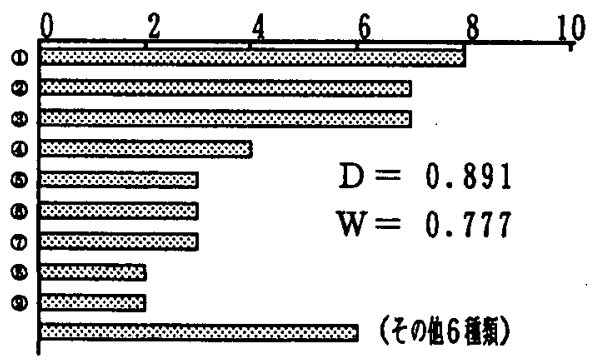

図 10. 大鵬 45 連勝の決り手

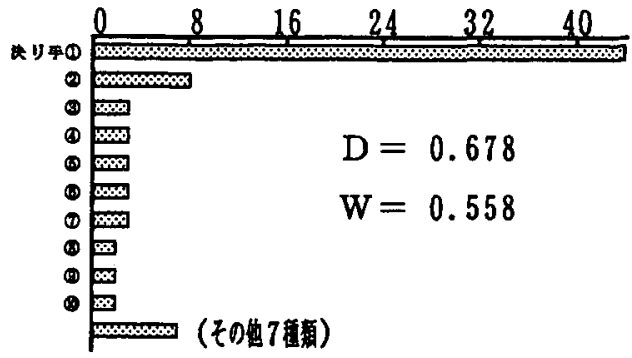

図 7. 貴乃花 80 勝（平成 8 年）の決り手

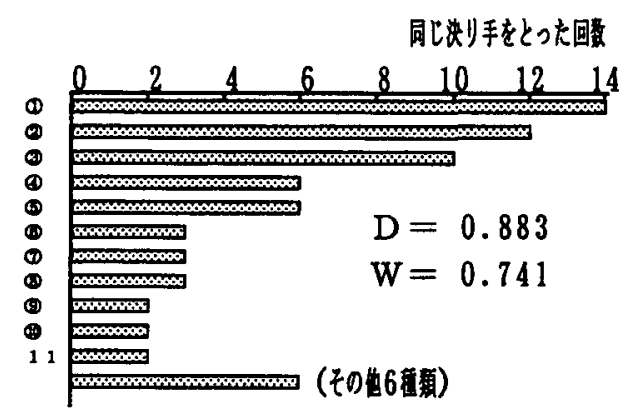

図 9. 双葉山 69 連勝の決り手

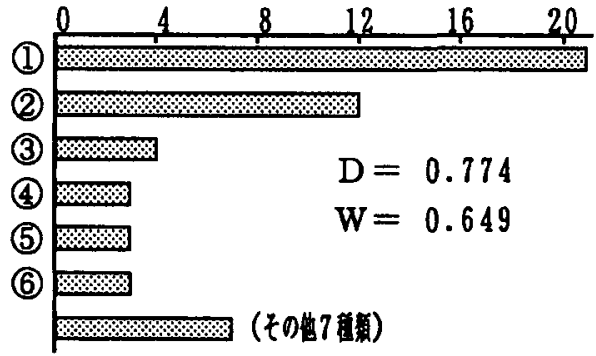

図 11. 千代の富士 53 連勝の決り手

そこで, とり得るカテゴリーの数が多く，データが多くなればより多くのカテゴリーに散らば る傾向があるときには， $\alpha>0$ として

$$
W_{\alpha}=r^{a} D=r^{\alpha}\left\{1-\left(\sum_{i=1}^{k} f_{i}^{2}\right) / n^{2}\right\}, r=\frac{k}{n}
$$

のように修正した係数を考えてみる。

さて，朝日新聞社（1997）の 169 ページに，96 年の幕内全取組の決まり手の集計結果が与えら れている，それによると，寄り切り $29 \%$, 押出し 16\%で，この 2 つで全体の $45 \%$ を占め,さら に上位 10 種類では全体の $82 \%$ になる. 全ての力士が同じとは限らないから, 第 1 , 第 2 の手で 6 割, 上位 10 種類までで 9 割の確率となるようにすればよさそうであると見当がつけられる。そこ で，全部で 70 あるカテゴリーに入る確率を（パーセント表示で） 
$\{42,18,10,6,4,2, \cdots, 2,1 / 3, \cdots, 1 / 3,1 / 6, \cdots, 1 / 6,1 / 9, \cdots, 1 / 9\}$

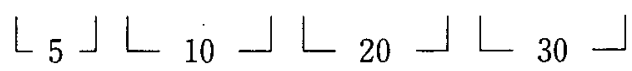

のように与えて，いろいろな $n$ についてのカテゴリー数 $(k)$ と散布度 $(D)$ ，そして $D に r^{\alpha}=$ $(k / n)^{\alpha}$ を掛けた值を算出する実験の, 10,000 回のシミュレーション結果を示したのが表 6 である. なお表 6 の NEC の列には，上記確率分布に対する非 0 のカテゴリー数の期待值が示してある.こ れは, 筆者が鈴木 (1997)で理論的に導出した結果で, $k$ の列の值と対比してみて, シミュレーショ ンがほ浽当な結果であることが分かる.

さて $k$ の值を眺めると, $n$ と共に増大する傾向がみられる.この $k$ の值を実際のデー夕と比較 してみると, 図 9 の双葉山や図 10 の大鵬が平均より多めで, 図 6（貴乃花）と図 8 (曙) は平均 以下，そして図7（貴乃花）と図11（千代の富士）はほほ平均の值であるといったことから, 想 定した確率の值がほほ妥当なものであることも分かる.

また，上記の確率に対する $\delta$ 值は 0.7738 であり， $n=100$ のときの $D$ に対するシミュレー ション值は 0.766 であるから,

$$
\alpha=\frac{n}{n-1} D=\frac{100}{99} \times 0.766=0.7737
$$

が $\delta$ よい推定值になっていることも確かめられる.ただ $n$ が小さいところでは, $D$ の值がやや 小さめになっていることが分かる，そこで，このD：にウェイトを掛けた場合の数值を眺めてみる と, $\alpha=1 / 2$ とした $r^{\alpha}=\sqrt{r}$ では $n$ と共に減少してしまうので失格である.比較的 $n$ に左右されな いのは， $\alpha=1 / 10$ か， $\alpha=1 / 8$ としたときのウェイトである。ルートを 3 回とればよいから， $\alpha=$ $1 / 8$ を採用して，このときの $W_{\alpha}$ を

$$
W=r^{1 / 8} D=r^{1 / 8}\left\{1-\left(\sum_{i=1}^{k} f_{i}^{2}\right) / n^{2}\right\}, r=\frac{k}{n}
$$

と置いて，散布度の指標として用いてみる。

図6〜図 11 には,この $W$ の值も示してある. 図7のWのほうが図 6 より小さく,また図 9 の $W$ も図 10 より小さめになっているから，Wという指標はサンプル数に関係しない散布度を示し ていると解釈できる。なおシミュレーションの結果から，Wの值が 0.65 を標準值とみなせば, 大 鵬，次いで双葉山が多彩な技を使うタイプで，千代の富士が標準的，そして（三連覇当時の）曙 と貴乃花が比較的一定の型で勝負をつけるタイプということになる.

なおここで定めたウェイトについては，カテゴリーの数や確率分布の与え方によっても結論が 多少変わるかもしれないので，この修正法はあくまでも大相撲の場合に限っていえることをお断 りしておく，最後に有益な助言を頂いた査読者の方々に感謝致します。

\section{参 考 文 献}

朝日新聞社 (1997) : 朝日キーナンバー 新訂第 3 版.

C. Gini (1913) : Sulla misura della concentrazione e della variabilita dei caratteri, Atti del R. Istituto Veneto di S.L.A., 73.

鈴木義一郎 (1997)：多項分布からの標本の非 0-セル (NEC)の分布について JAPLA '97 シンポジウム日本 APL 協会.

統計数理研究所国民性調查委員会 (1994)：国民性の研究, 第 9 回全国調査, 統計数理研究所 研究りポート75. 
カテゴリカルデータの散布度について

読売新聞社（1990-92）：大相撲（月刊誌）1990.8～1992.2（偶数月）.

（1997 年 1 月 17 日受付 1998 年 7 月 30 日最終修正） 著者連絡先： $=106-0047$ 東京都港区南麻布 4-6-7 統計数理研究所 